\title{
Major Genres of Country Music and Its Development
}

\author{
Jiaqi Mei \\ Jiujiang University \\ Jiujiang, Jiangxi province, China \\ E-mail: audiomjq@163.com
}

\begin{abstract}
Country music was formed in the countryside of southern America in the early 20th century. The ancient English folk songs, dance music and instrumental music are important sources of it. Black music, Latin music and music from other European regions also have enormous influences on it. At the same time, we can also find the concord and music structure in religious hymns in country music. Country music centralizes the quintessence of folk music of the white people. After a century of development, it gradually integrates into the modern industrial society and becomes an important part of popular music.
\end{abstract}

Keywords-country music; English folk songs; black music; rock music

\section{ORIGIN OF COUNTRY MUSIC}

\section{A. Promotion of Broadcast and Recording and Collection of Folk Songs}

Country music comes from the folk, but in the process of transmission, electronic media has played an important role in it. In the 1920s, America opened the video frequency band to the folk and the broadcast industry advanced rapidly, which brought keen demands for music. By 1929, there were more than 1,200 families that had their own radios in America. Thus large and small radio stations established one after another. The record industry had developed to a very mature state at that time and the record player was also quite popular in cities. Because of being influenced by the broadcast industry, record labels begin to find new popular music style to seize markets. They turn their eyes toward a large number of recording personnel who pour into the city, let them go to the vast land in the south, collect and record excellent country singers' records, which play an important role in promoting the country music to integrate into American popular music objectively.

\section{B. Hillbilly Music}

Country music derives from Hillbilly Music. In the 1920s, Henry Ford, the founder of Ford Motor Company, was extremely disgusted with the Black swing music in American, so he launched a movement to revitalize the traditional music culture of the white people, let dealers of Ford Motor in various regions hold traditional music games and finally held the final competition in Detroit. The mainstream newspaper used the whole length to report this spectacular event, which made traditional music become very popular at that time.
At this time, the radio also began to broadcast a lot of peasant music. With enormous appearance of country singers and bands, people were eager to come up with a name for this music with local flavor. In January 15, 1925, after completing the recording, a southern peasant band is required to name this band. Al Hopkins, the pianist, said, "Whatever name is ok. Anyway, we're just a group of farmers from the hilly area". Ralph Peer let the assistant mark on the music score that sang by "Hillbilly". So with broadcast of the program, the word "Hillbilly Music" was spread.

Hillbilly Music has simple tune and stable rhythm. The lyrics are narrative and have local flavor. Many works also involve religious theme. It is accompanied by the violin family, banjo and guitar.

\section{Promotion of "Grand Old Opry"}

Among all the radio stations, the one in Nashville in Tennessee in American South makes the most important contribution for the spread and development of country music. The "Grand Old Opry" broadcast in 1925 attracted a large number of country music artists. At first, they focused on instrumental music performance. Later, they played and sang by themselves. By the Second World War, it had developed to become the most influential broadcasting program of country music throughout America. The "Grand Old Opry" was called the cradle of country music. It has promoted and helped country music artists who enjoy some sort of reputation. Therefore, Nashville also becomes the birthplace of country music and the base camp where country music artists get together.

\section{MAJOR GENRES OF COUNTRY MUSIC AND ITS DEVELOPMENT}

\section{A. Western Swing}

The Great Depression happened in the 1930s in America made a great many of villagers in the south leave their hometown and head for the magical western region to look for new hopes. On this land, the Hillbilly Music brought by villagers in the south integrated with the optimistic and free and easy spirit in the west and generated the so-called "Western Music". In Western Music, the lifeful ranch life replaced the tranquil southern country life and became the main content in songs. 
In the late 1920s and early 1930s, Jimmy Rodgers, the "Father of Country Music" sang many songs about the western theme, such as When Cactus Blooms. Hereafter, country songs sung by Carl Sprague and Otto Gray appeared one by one. They took life in the west as the theme. People called it as "Cowboy Song".

At the same time, Bob Wells and Milton Brown combined western country music with swing jazz that was popular throughout the country, and produced "Western Swing". Brown died young in 1936 and he couldn't further give play to his talents. While Wells organized the famous band of "Texas Cowboy", and became active in American music circles in 1930s and 1940s. They matched the drum, brass-wind instruments of jazz style with violin of country music style to play warm and cheerful music, which is very popular among audiences. They once created the brilliant era when the sales volume of singles is over one million.

\section{B. Bluegrass Music}

The Bluegrass Music was another branch of country music appeared in mountainous area of Kentucky in 1940s. On the basis of country music, it absorbed the banjo music and violin music in the local ancient "Corn Threshing Party" and narrative songs in southern mountain areas.

The singing of Bluegrass Music is often multi-voice. It focuses on cheerful melody. Except for the part of the main melody, it often uses falsetto to overlay a harmony part above, and sometimes adds one or two bass voices below the main melody. Its accompaniments of musical instruments mainly are banjo and violin. Sometimes it adopts folk musical instruments such as mandolin and contrabass, etc. Bluegrass Music also maintains the characteristics of traditional country music that it has no drum set. The speed of Bluegrass Music is relatively fast. Most of the rhythms are 160 to 330 beats per minute. In the 1930s, the dry law that had implemented in America for 13 years was relieved, so large and small bars appeared in many areas.

In the first place, the country music that appears in places such as public ball and places for regional competition has a new place for playing-bar. The environment in bars is noisy. The customers are often rude and great-hearted bluecollar workers. The changes of environment also make country music change accordingly. After the Second World War, country music played in this kind of bar also forms gradually. Electric guitar replaces acoustic guitar and becomes the main music instrument. Drums and the piano are often brought in. The influence of music is bigger and the chord is denser. The contents of songs often focus on the difficulties and hardships in life of blue collars, confusions on emotions and drinking and amusement. People call this kind of music as "Bar Music".

In the process of development, Bluegrass Music is influenced by jazz music. Representatives have: Bill Monroe and "Bluegrass Boys" led by him, "Osborne Brothers", "Johnson Mountain Boy" and "Nashville Bluegrass Band", etc.
In the 1970s, with the popularity of rock music, other country music kept abreast of the situation and widely adopted electro acoustic musical instruments, while the Bluegrass Music insisted using traditional musical instruments and once hit rock bottom. In the 1980s, the "Bluegrass Renaissance Movement" appeared in the name of "New Grass" attracted a large number of young audiences. The representative band is the band of "New Grass Renaissance".

\section{Nashville Sound}

Before the Second World War, although country music had been widely spread, on the whole, it is still a regional musical type. In 1950s and 1960s, the influence of country music is further enlarged. It became the popular music form that has national influence and was formally called as "Country Music".

Nashville in Tennessee is the production center of American country music and plays country music throughout the country. Radio stations and TV stations in this area are famous. The WSM broadcasting station in Nashville kept its flag flying for decades since it had broadcasted the program of "Grand Old Opry" in 1925. When it comes to the 1950s, it had become a national program and the number of field audiences reached several thousands. Nashville at this time had formed the mechanism of a coordinated process, including discovery of singers, record, publishing and release. In 1958, American Country Music Association registered in Nashville, which further laid its foundation of "Capital of Country Music".

Under this background, a kind of country music style full of Nashville characteristics was born at the right moment. People called it as "Nashville Sound". Looking from the style, it belongs to country music and popular music in between. It has not only the native characteristics of country music but also characters of times of popular music. It mainly takes piano, string music and background harmony as music basis. Compared with the accompaniment of violin and banjo of traditional country music, it is more popular. Musicians who represent this style mainly have Roy Acuff, Hank Williams and Patsy Cline, etc.

In the 1960s, almost more than half of the records in America were from Nashville. Under the scheme of music producers represented by Atkins, a large number of super stars flickered in the sky of Nashville, such as songstress Patsy Klein and Jim Reeves, who got splendid reputations. At the same time, the rock music sprung up in the middle 190s also had comprehensive influences on country music.

\section{Rockabilly and Country Rock}

Rockabilly is the integration of country music and rock music. In the late $1950 \mathrm{~s}$, rock music began to become popular throughout America. Some country artists based on traditional hillbilly music, and abandoned the violin family and banjo, began to adopt the band configuration of rhythm and blues, introduced musical instruments such as electric guitar and saxophone, and strengthened the intensity of drum and bass. This style sounds like rock music without losing 
the characteristics of country music and it gained popularity among country music fans and rock music in the 1950s.

Country Rock was the second integration of country music and rock music and prevailed in the 1970s. It is a kind of integrated country music created by rock players who refer to elements of country music. They integrate a great deal of country music and blues into rock music, and adopt typical country rhythm and harmony. This emotionexpressing theme brings great appeals. With the use of electro acoustic musical instrument of rock music, it is warmly welcomed by young people.

\section{E. "Outlaw" of Country Music, New Traditionalism and New Country}

1) "Outlaw": The "Outlaw" here is the alienation for the commercialization of the Nashville Sound. In the system of Nashville, the producer chose songs for country singers and arranged the production of music. Many independent and creative singers all left Nashville to go to Austin in Texas. The central person in Outlaw is Willie Nelson. His individualized new trials are rejected by Nashville. The annual concert begins in Austin and attracts other singers and music composers who are not noticed by people, such as Whalen Jennings, etc. Their rustic trials that seek the roots are to keep the rustic even barbaric personalized expression that appears before the country music goes all the way to cater to popular taste. "Outlaw" was welcomed by senior country music fans and got response in the broadcasting station and campus. In 1976, the Wanted! The Outlaws created by Willie Nelson and Whalen Jennings achieved great success and became the first platter that reaches millions of sales volume in the history of country music.

2) New Traditionalism: The country music after $1980 \mathrm{~s}$ presented the situation of diversified development. The infiltration and combination of styles became closer and closer, while ordinary boundaries became more and more vague. On the whole, there are two trends. One is partial to popular music, and the other is partial to traditional country music.

On one hand, the popular country music has plenty of audiences and creates excellent business performance, and also brings up many well-known super stars, such as John Denver and Kenny Rogers, etc. The time when John Denver was in vogue stretched across the 1970s and 1980s. His songs such as Take Me Home, Country Roads are spread throughout the world and he had loyal fans around the world. But even though Kenny Rogers's songs have distinct characteristics of popular music and he has never won awards from Country Music Association, his narrative singing style and slow and melodious feeling tone are undoubtedly marked the brand of country music.

On the other hand, because country music gradually becomes similar to popular music, people's voices for returning to traditional country music are increasingly higher, and styles such as "New Traditional Music" and "New Country Music" appear correspondingly. They try hard to find the simple and sincere nature of country music in traditional music styles such as Bar Music, Western Music and Bluegrass Music, and then grasp the roots of country music.

The singer George Strait is the representative personage of new traditional music. His music combines the outburst of enthusiasm of Bar Music and Western Music, but gets rid of the excessive vulgar parts. Meanwhile, he also uses popular electro acoustic musical instrument and the contents of music also focus on narrating urban stories to cater to the tastes of urban audiences. The songs in the style of Strait are called "Urban and Rural Songs". Its recovery of original simplicity attracted many fans and it occupied an important position in country music in the 1980 s and 1990 s.

3)New Country: New Country was begun in the middle 1980s and it was the continuation of New Traditionalism. But it put more emphasis on electro acoustic rock music. Later this genre advocated keeping the style of traditional country music. Some people represented by Clara wore jeans and cowboy hats to show their music must return to the situation in the early time. After the 1990s, New Country became a general term and referred to the popular music that has the sources of country music.

In addition, many country singers try to create popular music, so that it is difficult to distinguish between country music and popular music. Representatives in this aspect sprung up in the 1970s. Chinese audiences are quite familiar with them, such as John Denver, and the song of Take Me Home, Country Road created by him is widely known in China.

\section{REFERENCES}

[1] Wrote by NeilHaislop, translated by Gu Tianjue, Master of Country Music [M], China Youth Publishing House, 1998

[2] Tang Xiaoyu. Singing Technique of Country Song and Rock Musicthe Most Popular Country Music Singer and Country Music [J], the World of Music, 1994(11)

[3] You Jingbo. The Pure and Fresh Country Music [J], Musical Instrument, 2006

[4] Wang Jie. Analysis on the Development History of the Combination of Country Music and Rock Music in the 20th Century [J], Grand Stage

[5] ]Cheng Mingdao, Song Jinwei. Folk Art Losing the Soul-Evolution of American Country Music [J], People's Music, 1986

[6] He Xide. The Philharmonic Road (29) Introduction to Western Popular Music (Volume Two)-Disco, Rock Music and Country Music [J], Audio Technology

[7] Shi Wenhua, Li Wan. Informal Discussion on Country Music [J], Audio Visual Technology, 1997(08) 